The Role of Strategic Groups in understanding Strategic Human Resource Management

Authors

Gannon, J, M., Doherty, E.J. \& Roper, A.J.

PERSONNEL REVIEW 41(4):513-546 - MAY 2012 


\title{
The Role of Strategic Groups in understanding Strategic Human Resource
}

\section{Management}

\begin{abstract}
Purpose - This article explores how understanding the challenges faced by companies' attempts to create competitive advantage through their human resources and HRM practices can be enhanced by insights into the concept of strategic groups within industries. Based within the international hotel industry this study identifies how strategic groups emerge in the analysis of HRM practices and approaches. It sheds light on the value of strategic groups as a way of readdressing the focus on firm and industry level analyses.
\end{abstract}

Design Methodology/Approach - Senior human resource executives and their teams across eight international hotel companies (IHCs) were interviewed in corporate and regional headquarters, with observations and the collection of company documentation complementing the interviews.

Findings - The findings demonstrate that strategic groups emerge from analysis of the HRM practices and strategies used to develop hotel general managers (HGMs) as strategic human resources in the international hotel industry. The value of understanding industry structures, dynamics and intermediary levels of analysis are apparent where specific industries place occupational constraints on their managerial resources and limit the range of strategies and expansion modes companies can adopt.

Research limitations/implications - This study indicates that further research on strategic groups will enhance the theoretical understanding of strategic human resource management (SHRM) and specifically the forces that act to constrain the achievement of competitive advantage through human resources. A limitation of this study is the dependence on the human resource divisions' perspectives of realising international expansion ambitions in the hotel industry.

Practical implications - This study has implications for companies' engagement with their executives' perceptions of opportunities and threats, and suggests companies will struggle to achieve competitive advantage where such perceptions are consistent with their competitors.

Originality/value - Developments in strategic human resource management have relied upon the conceptual and theoretical developments in strategic management, however, an understanding of the impact of strategic groups and their shaping of SHRM has not been previously explored.

Keywords Strategic groups, Strategic human resources, Strategic human resource management, International human resource management

Paper type Research paper 


\section{The Role of Strategic Groups in understanding Strategic Human Resource Management}

\section{Introduction}

Most developments in strategic human resource management (SHRM) and international human resource management (IHRM) have drawn heavily on the strategic management literature (Becker \& Huselid, 2006; Bratton, 2007; Schuler \& Jackson, 2007). Some of the earliest models associated with SHRM (such as Fombrun, Tichy \& Devanna, 1984; Beer, et al., 1984; Hendry \& Pettigrew, 1986 and Guest's model, 1989) provide insights into how leading HRM thinkers have approached the strategic dimensions of HRM. Such insights have focused upon the links or fit between strategy and HRM, environmental analyses as the basis for strategic management informing (and in some cases informed by) HRM, and borrowing concepts and theories with their origins in the strategic management literature, such as organisational and product life cycles, and competitive strategies (Schuler \& Jackson, 1987; Sanz-Valle, et al., 1999; Miles \& Snow, 1984). Despite the advances made in both areas there has been minimal consideration of the ways that strategic groups, not only industries and firms, influence HRM strategies and practices in the pursuit of competitive advantage (Boxall, 2003). Strategic group research identifies how groups of firms engage in similar strategies in order to compete effectively within industries and shape industry structure and competition. Panagiotou (2006 p.440) defines strategic groups as:

those groups of firms within an industry, which are characterised by similarities in their structure and competitive beliefs as well as their tendency to follow similar strategies along key strategic dimensions in a specific operating environment.

The performance differences between strategic groups are the focus for much of this research, but mobility between groups and the structural dimensions of industries have also received attention (Ferguson et al., 2000; Leask \& Parker, 2006; Porter, 1980; Reger \& Huff, 1993). As such strategic group research has developed as a central research theme in strategic 
management. One of the most notable aspects of strategic groups research is that it highlights and reinforces the importance of particular industry contexts. This is an important consideration for the development of SHRM research as there is now growing recognition of the value of industry and sector specific SHRM research where the nuances and structural dimensions of industries are emphasized (Boselie et al., 2009; Paauwe, 2008; Paauwe \& Boselie, 2008; Tyson \& Parry, 2008).

The aim of this study is to explore how the strategic group concept can inform SHRM approaches. Specifically it sets out to identify how strategic groups can help us understand why companies struggle to achieve sustainable competitive advantage. This aim is achieved by initially investigating the strategic group literature and evaluating where it adds insight and value to the SHRM approaches literature. Thereafter the findings from an in-depth empirical study of the HRM practices and strategies deployed across a global industry are used to highlight the role of strategic groups in constraining companies' capacities to differentiate their SHRM approaches and practices. Accordingly this article also satisfies the demand for more sector led SHRM research (Paauwe, 2008; Paauwe \& Boselie, 2008; Tyson \& Parry, 2008).

This article unfolds as follows. Initially an evaluation of the strategic group literature is provided followed by an analysis of the contemporary debates in SHRM (Boxall \& Purcell, 2000; 2003; 2008; Boselie, Paauwe \& Richardson, 2002; 2003). The limitations of the SHRM literature are reflected upon in light of the strategic group literature and the potential contribution this field towards a more nuanced understanding of SIHRM approaches and practices. The research design for the study is subsequently outlined alongside an overview of the context of the research, the global hotel sector. The qualitative data analysis is then considered with the HRM practices and approaches which are found to be common across the whole industry, similar across particular strategic groups and distinctive to specific companies 
explored sequentially. The implications of these various layers of HRM practices and strategies, and specifically the strategic group dimension, are then discussed in relation to the extant research. Of specific note is the way such findings reinforce the challenges companies face when pursuing competitive advantage through human resources and how the national, industry and strategic group pressures for assimilation limit opportunities to develop idiosyncratic and integrated HRM interventions and strategic human resources.

\section{Literature review: Building bridges between Strategic groups and SHRM approaches}

\section{Strategic Groups}

The strategic group concept emerged within strategic management as an attempt to better understand the competitive backdrop and demands faced by companies operating in an industry (McGee et al., 1995; Porter, 1980; Short et al., 2007). Strategic management analysis has typically taken place at the level of the firm and the industry, and has omitted the interface of firm and industry competitor behaviour. Originating from the broader field of industrial organization economics in the 1970s, strategic groups were identified as clusters of companies within industries (Porter, 1980). Such divisions arise because industries are not collections of heterogeneous companies but subsets of firms separated by mobility barriers limiting movement between groups (Ferguson et al., 2000; McGee et al., 1995). Strategic group research has facilitated a better understanding of how group structure can shape rivalry and ultimately performance, as well as group identities and reputations. It has also illustrated how strategic group reputations serve to reinforce mobility barriers to other industry competitors (Dranove et al., 1998; Ferguson et al., 2000; Leask \& Parker, 2006; Peteraf \& Shanley, 1997). The analysis of the business environment as an objective reality, achieved classically through cluster or factor analysis of company data (Reger \& Huff, 1993), drives most investigations in this area. However, Panagiotou (2006 p.441) summarises the problems of this prescriptive approach as leading to: 
a preoccupation by managers that strategic management is all about prescribing strategies for positioning a business in a particular industry structure, having first carried out a thorough economic analysis based on the implicit notion that industry structures are relatively stable and easily identifiable.

More recently a cognitive approach to strategic group research has emerged based upon the argument that managers' simplification of their complex competitive environments and perceptions of similarities and differences among their rivals will shape strategic decisionmaking (Panagiotou, 2006; 2007; Reger \& Huff, 1993). Such managerial insights into competitive groupings offer clearer conceptions of the way decision-makers perceive their own organisations and their rivals and therefore how these determine and implement strategies. These arguments suggest that strategists' understand (and approach) their competitive environments in similar ways, and are related to the ideas of institutional assimilation and isomorphism (DiMaggio \& Powell, 1983; Powell \& DiMaggio, 1991). Therefore, the capacity of firms to pursue distinctive practices for competitive advantage may be limited by constraints, such as organisational inertia and forms of isomorphism (Reger \& Huff, 1993; Boon et al., 2009). Strategic groups are then another important aspect of the structural dimensions which foster this organisational sluggishness. These are critical insights where the pursuit of competitive advantage through human resources, HRM practices and strategies has gained substantial support in recent years (Becker \& Huselid, 2006; Boxall, 2003). However, this quest for distinctive or idiosyncratic HRM practices and strategies to attain competitive advantage needs to be resolved against the pressures to conform and achieve social legitimacy within sectors. The next section evaluates the contemporary SHRM approaches and highlights where the strategic group literature contributes to their enhanced understanding.

\section{The Strategic HRM approaches}

Three main SHRM approaches have emerged as the keystone for understanding and achieving sustained corporate success through human resources (Purcell, 1999; 2001; Boxall \& Purcell, 
2003; 2008). While the opportunities for simultaneously enacting these approaches are now well-rehearsed it is useful to revisit them briefly as part of developing the theoretical connection with the strategic group literature. The best practice SHRM approach encourages companies to adopt sophisticated or 'high performance' practices across their human resources in order to achieve competitive advantage (Pfeffer, 1998; Huselid, 1995). Considerable criticism of the best practice SHRM approach occurs in relation to what actually represents 'sophisticated' HRM practices and the empirical basis on which these practices are suggested (Marchington \& Grugulis, 2000; Boxall \& Purcell, 2003; 2008). Furthermore, the conventional best practice SHRM approach suggests that these superior HRM practices should be adopted regardless of different industrial and national boundaries (Marchington \& Grugulis, 2000; Boxall \& Purcell, 2003; 2008). Recent evaluations of the 'best practice' SHRM approach have emerged recognising that within industries there may be certain HRM practices and approaches which are obligatory (Boxall \& Purcell, 2003; 2008). The 'table stake' concept suggests there are established (HRM) practices adopted by all businesses in an industry which serve to legitimise their position in that industry. This concept has thus been recognised as an adaptation of the 'best practice' SHRM approach (Boon et al., 2009; Bjorkman, 2006; Boxall \& Purcell, 2003; Paauwe \& Boselie, 2003). The 'table stake' version of best practice SHRM approach is based upon the institutional assimilation literature where organisations struggle to distinguish themselves from their industry associates whilst simultaneously achieving legitimacy (institutional fit) in their sector (DiMaggio \& Powell, 1983; Powell \& DiMaggio, 1991; Oliver, 1997). Isomorphism is the process which constrains organisations' attempts to differentiate themselves within the same institutional context (DiMaggio \& Powell, 1983). Isomorphism emerges in two broad variations; competitive isomorphism where market pressures and performance targets are emphasised and institutional isomorphism where institutional factors associated with socio-cultural, technological and economic parameters are highlighted. 
The adoption of best practice SHRM approach across an international setting has also been roundly critiqued (Brewster, 1999; 2006; Sparrow et al., 2004) due to the ingrained national institutional and cultural conventions, which are seen to regulate the value of various high performance HRM practices in other countries (Brewster, 1991; 2006; Sorge, 2004). However, this does not mean that across a country all industries have the same HRM practices. Much of the IHRM literature could be seen as disproportionately focused upon the parent and host country cultures and systems in light of the evidence on SHRM approaches and practices in hospitals, local government and hotels (Boselie et al., 2002; 2003). Such studies indicate that institutional and competitive isomorphisms differ across industry contexts creating distinct table stake HRM practices in different industries within the same country (Boon et al., 2009; DiMaggio \& Powell, 1983). Furthermore, such evidence recognizes that national institutional dimensions may have less of an impact than competitive institutional dimensions on some industries and their resulting people management practices. This level of industry interplay on the best practice approach is valuable but in light of the strategic group insights it is clear that companies do not compete directly with every other company in their industry. Instead they are likely to have particularly close rivals whose practices, products, managers, innovations and initiatives will be of specific interest to them (Panagiotou, 2006; Peteraf \& Shanley, 1997). As such there may be another layer of consistency and similarity in HRM practices due to the close rivalry of strategic groups, in addition to those identified by the 'table stake' version of the best practice SHRM approach across an industry.

The 'best-fit' SHRM approach suggests a firm's market position and strategies drive and shape its HRM policies and practices. Within the 'best fit' SHRM approach a range of theories have emerged from those that more simplistically link specific strategy choices to HRM practices and policies (Delery \& Doty, 1996; Miles \& Snow, 1984; Schuler \& Jackson, 1987) to more 
complex models (Fombrun, et al., 1984; Hendry \& Pettigrew, 1986) which envision a range of corporate characteristics (strategies, positions, portfolio characteristics) determining people management practices. Within the IHRM area, much of the research has also focused upon the influential nature of national differences as well as strategic models (Perlmutter, 1969; Bartlett \& Ghoshal, 1989; 2000; Edwards et al., 1996). For example: the models of international orientation (Perlmutter, 1969; Heenan \& Perlmutter, 1979); product life-cycle phases (Adler \& Ghadar, 1990); and international responsiveness versus integration (Bartlett \& Ghoshal, 1989; 2000; Edwards et al., 1996) are all based upon strategic choice arguments derived from the strategic management field. The main thrust of the strategic dimension to IHRM has revolved around the question of whether HRM practices are determined by corporate or business strategies and customised or standardised across national boundaries with many authors providing detailed analyses of the contingency of specific factors (Boselie et al., 2002; 2003; Coller \& Marginson, 1998; Easterby-Smith et al., 1995; Ferner, 1994; Ferner, 1997; Ferner \& Quintanilla, 1998; Hannon et al., 1995; Newman \& Nollen, 1996; Rosenzweig \& Nohria, 1994; Rosenzweig, 2006; Thompson et al., 1998).

The weaknesses of the 'best fit' SHRM approach are its distorted attention on the external context as determining strategies and practices based on market positioning, cultural and institutional factors; and its inability to secure competitive advantage where several companies within the same sector pursue similar strategies and market positions (Boxall \& Purcell, 2003, 2008; Kamoche, 2001; Wright \& Snell, 1998). Such criticisms are similar to those voiced by contemporary strategic management researchers on the objective and prescriptive versions of strategic management being the primary influence on strategic thinking and decision-making at the expense of managers' and executives perceptions of positions and rivalries (Reger \& Huff, 1993). Indeed Panagiotou's $(2006 ; 2007)$ research on executives' perceptions, as opposed to the economic analysis of the competitive terrains, competitor strategies and industry dynamics 
shaping strategic groups, highlights that executives whose firms belong to the same strategic groups react to events and market factors in similar ways. This suggests, that not only are companies constrained by the suggested strategies and market positions they develop, but that there are limitations to the options they can take to distinguish themselves because of the added level of similarity strategic groups create.

Finally, the resource based view (RBV) SHRM approach has been proffered as an alternative to the best practice and best-fit approaches due its internal focus based upon creating competitive advantage through the leverage of valuable, rare, inimitable, non-substitutable and rent achieving (human) resources (Morris et al., 2006; Wright et al., 2004; Wright et al., 1994). The empirical research supporting the RBV SHRM approach (Boxall \& Steeneveld, 1999; Leonard-Barton, 1995; Marchington et al., 2003) clearly highlights that human resources can fulfil the criteria of resources which deliver competitive advantage. The most valuable human resources are those identified as the 'strategic human resources' or 'rainmakers' who fulfil the RBV criteria of adding exponential supplementary value to companies. By developing HRM practices, which are idiosyncratic and interdependent, the RBV approach argues that companies can capitalise on their proprietary knowledge and transfer it creatively and effectively across its workforce. Several authors (Bonache \& Fernandez, 1999; Harvey et al., 1999; 2000; Taylor et al., 1996) have adopted this approach and identified that capitalising on internal resources to achieve competitive advantage is quite different from the best-fit SHRM approach because it surmounts the external views of the best-fit approach. This view is neatly outlined in the frustrations of Cappelli and Singh (1992 in Wright et al., 2004 p.11):

"many within strategy have implicitly assumed that it is easier to rearrange complementary assets/resources given a choice of strategy than it is to rearrange strategy given a set of assets/resources, even though the empirical research seems to imply the opposite." 
The RBV SHRM approach offers specific insights into the value of internal resources in securing successful international operations (Bonache \& Fernandez, 1999; Harvey et al., 2000). Specifically particular groups of human resources are seen to have an honoured position within companies where they transfer tacit knowledge to new markets and provide sustainable competitive advantage (Prahalad \& Hamel, 1990; Scullion \& Starkey, 2000). Taylor et al.'s (1996) study used the RBV approach to identify the critical role of HRM competence within international firms, the part senior management play in identifying the company's potential to develop HRM competence and the different groups of human resources who constitute firm strategic human resources. However, the weaknesses of this SHRM approach are its omission to clearly depict the interplay between internal resources and environmental factors, and the recurring evidence that firms struggle with the challenges of their competitive sector to achieve distinctiveness and success through their human resources and HRM practices (Boxall \& Purcell, 2003; 2008). Once again the strategic groups literature provides specific insights here in querying whether the pursuit of competitive advantage through the leveraging of the firm's distinctive resources is restrained by the influence of their closest strategic group (Panagiotou, 2006; 2007).

Clearly each of the SHRM approaches (table stake best practice, best-fit and RBV) have some resonance and these perspectives are summarised in Figure 1 in terms of their initial focus and the levels of context where their attention is directed. There is an overall tendency across the SHRM literature for tensions, contradictions and imbalance (Boselie et al., 2009) as evidenced in the overly prescriptive best practice approach, the highly contingent best fit approach (focusing on specific market or national context factors) and the RBV's spotlight on the internal resources of the organisation. Individual adoption of these approaches is unlikely to provide a meaningful depiction of how companies might pursue competitive advantage via their human resources or HRM practices. Instead it is argued that companies can use a 
combined and simultaneous version of the three SHRM approaches in an attempt to balance the external and internal perspectives adopted by the best-fit and RBV approaches, whilst also recognising the important influence industry isomorphism (table stakes) has on the creation of a set of HRM practices (Boxall \& Purcell, 2003; 2008).

\section{Insert Figure 1 here}

Even where such a combined and simultaneous model of SHRM has been advocated (Boxall \& Purcell, 2003; 2008) there appears insufficient understanding of, and insight into, the industry or sectoral level of analysis (Boselie et al., 2009; Boxall, 2003; Paauwe, 2008; Paauwe \& Boselie, 2008). By exploring SHRM practices and approaches across an industry, rather than across specific national or company contexts, a better understanding of the internal and external challenges faced by competing organisations to achieving distinctive HRM strategies and practices becomes manifest. Alongside this evaluation of the SHRM approaches, the strategic groups literature highlights that these clusters of close rivals may compound the challenges firms already face in realising differentiation through their human resources and HRM practices. Indeed where industry analyses highlight the importance of conformance of industry members, to particular HRM practices and systems, strategic groups suggest another layer of orthodoxy amongst closest rivals which limit the pursuit of distinctive competitive advantage by firms.

\section{Research Design}


Analysis of strategic groups requires an industry focus and this research was undertaken within the context of the international hotel sector. This sector has been identified as international by nature (Litteljohn, 2003; Litteljohn et al., 2007) with companies achieving growth through a range of market entry modes, typically engaging with different equity partners (Bender et al., 2008; Whitla, et al., 2007). Managing portfolios of hotels with diverse ownership arrangements (such as the asset light options of management contracts, franchises and part equity agreements) has created challenges for international hotel companies (IHCs) (Beals, 2006; Eyster, 1997; Gannon et al., 2010; Guilding, 2006). Traditionally hotel general managers (HGMs) have been seen as strategic human resources (Boxall \& Steeneveld, 1999; Marchington et al., 2003) responsible for creating profitable hotel units through their leadership and operational expertise in the hotel industry (Forte, 1986; Kriegl, 2000; Ladkin \& Juwaheer, 2000). However, the asset light market entry modes developed more recently as a result of IHC portfolio expansion have resulted in managers and executives experiencing different challenges and requiring enhanced skills sets. At the heart of this study was the aim to explore how IHCs have developed IHRM strategies and practices to manage their international managerial resources within the broader context of the sector's competitive forces, growing industry concentration and in the presence of strategic groups (Curry et al., 2001; Litteljohn, 1999; Roper, 1995).

Any attempt to capture people management strategies and practices across an industry, as well as at the firm level, involves the adoption of a comprehensive sample of organisations. This study used an industry definition of global operations based on companies operating hotels across five out of the six economically viable continents, as a purposive sample technique (Bryman \& Bell, 2007; Saunders et al., 2000). This research stage comprised substantial secondary data collection on the broader international hotel industry with information on service levels, ownership modes, brands, portfolios and geographical penetration and the 
information is captured in Table 1. Only nine companies met these global criteria and eight of these nine companies granted access to their senior human resource executives (typically Vice Presidents of Human Resources) and administrative teams, and HR systems and materials. The fieldwork interviews took place at the European corporate headquarters, regional offices and in hotel units for the eight companies. Interviews with the senior HR executives for each of the eight companies form the main part of the data. These interviews lasted around four hours on average. In addition, time was also spent with administrative teams, reading documentation and observing meetings. A checklist was developed to complement the interview questions and data, and to systemise the collection of company documentation, observations and interactions with the administrative teams (Bryman \& Bell, 2007; Robson, 2002). Documentation included HRM policies, performance appraisal forms, training manuals, organisational charts, company communications, job descriptions, succession plans and demonstrations and hard copies of HR databases. The interview transcripts, fieldwork notes and documentation allowed cases to be written for each company which were sense-checked by industry informants and against the research team's notes and observations.

\section{'Put Table 1 here'}

Access was granted to the eight companies on the basis of offering confidentiality to participants and organisations. Each company was protected through the allocation of pseudonyms and all data and notes collected removed company names and trademarks to provide confidentiality. This is in keeping with the widely acknowledged difficulties of gaining access within this industry (Litteljohn et al., 2007; Ropeter \& Kleiner, 1997). 
The cases built on the interview transcripts, observations and company documentation data meant that qualitative analysis was achieved through the tools and computer aided techniques recommended by key authors (Miles \& Huberman, 1994; Silverman, 1997; 1999). The process of initial coding identified HRM practices, management criteria and company strategies and characteristics. Descriptive coding was then used to highlight specific activities and relationships between HRM practices and approaches, and company characteristics. Further interpretive coding and analytic coding were highlighted through the themes presented by the respondents and the theoretical relationships arising from the data and initial coding (Silverman, 1997; 1999). Of particular importance were the themes of similar and distinctive HRM practices deployed by the companies, strategic groups and across the sample.

\section{Results}

Across the sample of eight IHCs evidence of common HRM interventions deployed included: a reliance on strong internal labour markets for unit management positions; training programmes with universal components; the use of performance appraisal as a mechanism for monitoring and evaluating human resources talent, the deployment of specific contractual agreements and conventions; the recurrent use of corporate communications channels; and specific HRM responses to cultural and international challenges. The shared aims of these practices indicated that the IHCs were adopting the table stake version of the best practice SHRM approach across their international portfolios (Boxall \& Purcell, 2003; 2008; Boselie et al., 2003; 2009).

The next stage of data examination involved the identification of company specific HRM practices based upon the best fit and RBV SHRM approaches. However, subsequent analysis of the qualitative data began to identify another layer of similar HRM interventions centred on the appearance of strategic groups within the sample. There appeared to be similarities between the companies based upon strategic variables such as parent company ownership, the scope of 
the hotels organisations' activities (levels of internationalisation, geographical coverage, and market segments); resource commitments (including size, brands and market entry modes); and centric and transnational orientations. As a result the sample was demarcated into three strategic groups. These are labelled the Multi-branders, Mixed Portfolio Purchasers and Prestige Operators. Table 2 summarises the strategic similarities and differences between the three groups and their IHC members.

\section{'Put Table 2 here'}

Patterns of HRM interventions across the three strategic groups are apparent from the data supplied by the executives, their teams and the documentation. These patterns focus around six areas: (1) the levels where HRM is focused, (2) different views about management skills and transferability across brands, (3) how international and domestic operations function, (4) extent of owner influence and cultural differences, (5) how and where managerial talent is found and (6) where specific career interventions emerge. Table 3 captures some of the comments from interviews across these six levels and the three strategic groups. The HRM interventions and features developed by the three strategic groups are outlined in Table 4 along with the strategic variables which distinguish the groups.

\footnotetext{
'Put Table 3 here'
}

\section{Strategic Group 1: Multi-branders}


The sheer size and scale of their multi-branded operations indicated parallels between the HRM approaches taken by the Multi-branders (see comments in Tables 3 and 4). Both companies boasted a critical mass of hotels in key countries or regions of the world resulting in more localised recruitment and development approaches. For example, they operated 'UK only' management training schemes and then specific recruitment initiatives tailored to educational systems, notably the French training and German apprenticeship schemes. The size of these two companies also meant they allowed their distinct brands to develop individually which had apparently resulted in some specific brand HRM practices. Both companies recognised there were few opportunities for managers to transfer between the different brands leading to bottlenecks in internal labour markets, where some brands grew more quickly and offered extensive transfer and promotion possibilities.

\section{'Put Table 4 here'}

The Multi-branders had attempted to deal with these issues in slightly different ways, though both now had structures, enabling moves between managerial levels across brands to achieve some overall parity across their company. In one company (Euromultigrow) there was a guide to the different positions within each brand to encourage internal brand transfers of human resources. This guide was based upon extensive negotiations with managers across the company's brands, although parent country nationals (PCNs) dominated amongst these managers and the company's University was responsible for the roll-out training for this guide.

Franchiseking had developed a competency-based HRM system designed to identify common areas of expertise across its brands and as one HR executive identified all managers with line 
responsibilities had to attend and use this framework. The competencies were developed in accordance with a HRM consultant firm and used existing and future 'high potential' managers across the company's portfolio to identify appropriate behaviours of successful managers. Competencies were heavily influenced by the company's existing management team comprising mainly PCNs. The company then ran a series of training sessions for its senior managers so the competencies formed the basis for all selection, performance appraisal, promotion and training decisions and activities. These attempts to closely manage their large portfolios of standardised brands across geographically disparate locations meant the Multibranders adopted an ethnocentric orientation to internationalisation with PCNs dominant in subsidiary management positions, which runs somewhat counter to their critical mass of units and attempts to localise too.

The Multi-branders commented less extensively, compared with the members of the other two strategic groups, on the level of interference from property owners where management contracts were used. They argued this was probably because their highly standardised brands, even at full-service levels, meant owners knew what to expect, and they did not attempt to interfere in the day-to-day management of hotels. The selection of managers for managed properties was also less troublesome for the Multi-branders. In most cases executives could appoint whomever they wanted and only in a few hotels or in specific countries and with specific types of owners (for example, governments) were there two or three managers presented to owners in a 'beauty parade'.

The Multi-branders were more concerned about the co-ordination of franchise operators and training and communication were seen to be vital mechanisms for managing these issues. These were the only companies who identified mandatory training courses for managers and held specific courses that their franchise partners were obliged to attend. Constant travelling by 
corporate executives was seen to further reinforce company values and assist in harmonization between geographically disparate franchised, managed and owned units. Both companies showed evidence of strong similarities associated with managing their multi-branded, and multi-market entry strategies and large, diverse portfolios. Dividing their HRM interventions into areas or countries where there was a critical mass of units was appropriate given the scale of their operations. Strong values, often based on the origins of the company, were communicated through frequent communiqués and training opportunities further reinforced the brand standards and achieved appropriate levels of corporate synergy in the face of competition from their smaller but potentially more nimble competitors.

\section{Strategic Group 2: Mixed Portfolio Purchasers}

The Mixed Portfolio Purchasers had been through considerable periods of change and growth prior to the researchers' fieldwork. In addition to acquiring smaller European hotel chains they had substantially expanded their domestic and international portfolios through other acquisitions and mixed market entry methods. Both had international and larger domestic sections which were managed almost completely separately, although they operated at similar market levels. While their existing international managers had primarily 'worked their way up through the company' the executives and administrators interviewed indicated lower proportions of internal HGM appointments (75-80\% compared to $90-95 \%$ in the companies of the other strategic groups). In addition, deputy HGM positions had previously provided a 'risk free' training ground for HGMs but restructuring activities a decade earlier had eliminated most deputy roles within the Mixed Portfolio Purchasers. The HR executives were resigned to such restructuring activities but held reservations about the long-term implications for aspiring managers and talent development.

Both organisations took a 'blanket' approach to recruitment combining every aspect of coverage of potential hotel management talent. They relied heavily on the 'grapevine' or 
industry network to identify possible external recruits at the senior unit management level. They also recruited specifically from the international hotel schools in Switzerland and the Netherlands. One company positioned such recruits in junior management jobs while the other provided a management development programme. In addition, the HR executives and their teams identified that speculative applications were encouraged from 'second jobbers', graduates who had undertaken some form of international experience, and who were now ready to settle down and develop their careers. Specific recruitment initiatives also existed for locations where the two companies had a critical mass of units (UK, Southern Europe and Germany) allowing these units their own junior management recruitment initiatives. However, managers from their domestic hotel brands were not deemed appropriate for their international properties as they lacked the necessary international experience and language skills.

The acquisitions undertaken by the Mixed Portfolio Purchasers had resulted in fervent attempts to build strong, coherent corporate cultures in their newly enlarged organisations. While all the IHCs had mentioned corporate communication as an important facet of managing international human resources the Mixed Portfolio Purchasers emphasised the value of communicating to their newly merged companies. Such communications still typically took place through top down processes; holding regional and HGMs meetings where company values were disseminated. Newsletters were also produced along with other documents informing staff of events, news and company priorities. Both Mixed Portfolio Purchasers were adamant that their acquired businesses had developed some effective HRM interventions and attempts had been made to adopt and adapt these practices, with mixed success. They also highlighted problems of over-staffing in their acquired firms and these had been dealt with through restructuring in an attempt to squeeze as much value out of the acquisitions as possible. However, the respondents remarked that these activities had not always been well-timed or popular, and their 
long-term ramifications would have implications for future human resource and talent development.

Succession planning practices existed in this strategic group though one company took a more sophisticated and IT-led approach to succession, linking it to their performance appraisal and a management training programme. Both Mixed Portfolio Purchasers had created profiles of their hotel units to help in the selection of HGMs. These were based upon the location and size of the unit, owner relations, marketing needs, customer groups, staff relations and the complexity and maturity of each business. However, the respondents were unsure as to how Regional Operations Directors exactly used these profiles to match managers to hotel properties. The Mixed Portfolio Purchasers were large companies eager to grow further but their acquisitions had provided considerable challenges to the effective development and management of their managerial resources. It was difficult to detect a clear international strategic orientation as they had leap-frogged stages through their acquisitions. Time to evaluate HRM practices and managerial talent was required but the executives and their teams were not afforded the resources (time or capital) to do this effectively. The Mixed Portfolio Purchasers were then positioned somewhere between the Multi-brander and Prestige Operator groups, in a state of flux. They were concerned with realising the value from their acquisitions by reducing overheads and assimilating effective practices across their organisations, rather than harnessing the resources and expertise of their HRM practices and managers to achieve competitive advantage through human resources.

\section{Strategic group 3: The Prestige Operators}

The four companies in the Prestige Operators strategic group provided the most extensive range of international and integrated HRM practices and approaches to manage HGMs. Their focus on luxury hospitality facilities and a more selective portfolio of hotels in key gateway 
locations across the world influenced their management of human resources in specific ways. The four companies were very proud of their international management cohort and the practices used to manage them, though they admitted that their recent corporate expansion plans made the supply of managerial human resources more challenging. Specific HRM practices had been enacted within the Prestige Operators to alleviate such issues and to ensure that strategic objectives related to growth and the maintenance of standards were achieved. They recruited almost exclusively into their management development programmes or directly to junior management positions from European hotel schools. In addition, they all ran management development programmes designed to advance the progress of talented managers from their existing staff to HGM positions within eight to ten years. These development programmes identified junior staff via performance appraisal systems and senior unit management reviews. They then attended assessment centres run by corporate and regional HR and operational specialists. Two members of this group had formal management training programmes where diploma and degree graduates joined and were provided with insights into key hotel departments. The other two organisations did not have such schemes but recruited the same calibre of graduates to junior management positions, though these recruits attended specific training courses and were tracked through regional and corporate HR systems.

The importance of mobility and international transfers were highlighted by all respondents from the Prestige Operators group indicating that international flexibility and cultural adaptability were vital for aspiring managers in line with their geocentric ambitions. The value of international experience was prioritised based upon the nature of the clientele, not only providing international hotel service standards but also customising these sensitively to local traditions and conventions. Managerial staff were not the only human resources encouraged to gain international experience, as these IHCs had developed international transfer opportunities for staff at all other levels too. Three companies offered sabbaticals for operative staff, while 
the fourth was about to introduce such a scheme following feedback from their recent employee attitude survey.

The Prestige Operators also exhibited more integration between their HRM practices. For example, their succession planning, performance appraisal, training and development programmes, transfers and career management activities were all co-ordinated which led to a high level of consistency in terms of the managers identified against the criteria set by the companies as future talent. One of the ways the companies achieved such integration was through the use of computerised systems of managers' details, where issues of mobility, succession planning, human resource planning and the level of managerial talent generally, could be discerned.

The HR executives in the Prestige Operators were themselves in much more powerful positions, compared with their other strategic group counterparts, where senior operational managers often held the reins in HR decisions. The Prestige Operators HR executives were more likely to work alongside their senior operational colleagues, have the power of veto over some appointments and moves, and generally seemed to have a more positive and proactive influence in their companies. Despite the strong similarities between the HRM practices and approaches taken to managing strategic human resources the Prestige Operators all claimed that their tactics meant they were breeding better managerial talent than the competition. Comments such as 'It's not what the rest of them are doing!' and 'We're producing managers who'll outplay the competition' signified what they felt was their departure from the established practices used to manage and develop HGMs. There is some evidence to support these claims as they demonstrated more sophisticated, co-ordinated and coherent HRM activities to ensure sufficient quantity and quality of international HGMs. However, these interventions took place in a more challenging context, as they reported more extensive 
problems of managing owner relations and coping with local and cultural differences, in line with their geocentric orientation (Perlmutter, 1969), and acknowledged in more detail the problems of standardising and customising HRM practices within and across their hotel units. Such matters were seen to be due to their more sensitive and adaptive approaches to serving international customers and developing partnerships through management contracts with local businesses. In short their industry positions, as global and luxury hotel service providers also suggest a wider range of challenges in managing and developing their human resources.

\section{Discussion}

The evidence of strategic groups, highlighted through the extensive similarities in HRM strategies and practices across the eight IHCs, presents a valuable insight into the opportunities for and limitations to creating competitive advantage via human resources and HRM practices. Overall the discussion of the results surfaces around two main themes; those that refer to the strategic human resource management (SHRM) approaches, and those that emphasise the insights from the strategic groups themselves.

In relation to the SHRM approaches, the results support the latest arguments that the table stake best practice approach emerges via a set of HRM practices which firms adopt in order to be socially legitimate in that industry (Bjorkman, 2006; Boxall \& Purcell, 2003; Paauwe \& Boselie, 2002). The common HRM practices implemented across the IHC sample occurred because of the specific nature of companies' internationalisation and development within the industry, and the occupational conventions and communities associated with managing hotels (Bender et al., 2008; Nickson, 1999; Roper et al., 2001). This is evidence that industry and competitive institutional forces (DiMaggio \& Powell, 1983) play an influential role in creating conformity in HRM practices across the IHCs (Boxall \& Purcell, 2003; Morris et al., 2006; Paauwe \& Boselie, 2002). While there was also evidence of the IHCs deploying integrated and 
distinctive HRM practices it was not as compelling or as apparent as the similarities found. Despite the claims of uniqueness made by all the HRM executives, their teams and the documents they supplied, only three companies were judged to have developed sufficiently idiosyncratic and integrated HRM practices in line with pursuing a RBV SIHRM approach to achieving competitive advantage via their human resources. These three companies, comprising one Multi-brander (FranchiseKing) and two Prestige Operators (Globalalliance and Contractman International), were singled out as performing the RBV SIHRM approach not only due to their distinctive HRM practices but also because of their overall attempts to bundle practices and achieve coherence and synergy between their human resource strategies and interventions (Kamoche, 2001). Three companies demonstrating any semblance of the RBV SHRM approach suggests that, although firms purportedly strive for competitive distinction through their human resources and associated practices, the pressures for conformance are strong (Bjorkman, 2006; Boselie, et al., 2002; 2003).

The specific nature of an industry is important here as it suggests that different industries will be influenced in contradictory ways by the institutional and competitive influences at play. Previous studies on the international hotel industry have highlighted a lower level of national institutional impact in comparison to other sectors (Boselie et al., 2002; 2003). In addition, the dominance of American companies at key stages in the industry's expansion (Nickson, 1999) has also led to a suggestion of an American model of growth across the industry. Further research is required to understand how the American model has evolved more recently and whether other industries and sectors have experienced similar heritage issues within HRM and other areas of management.

It is not only the 'table stake' version of the SHRM approach but another level of convention, identified through strategic groups, which limit companies' capacity to differentiate themselves 
through their HRM practices and strategic human resources. The 'best fit' SHRM approach may suggest that HRM practices and strategies are determined by firms' strategies and market positions, but within close and competitive industries distinction via market position and strategies may be insufficient. The respondents identified how their HRM practices and policies for developing their managers were justified by their strategies, portfolio characteristics and market positions. However, the eight IHCs fell into three strategic groups based upon their similar market positions, international orientations, portfolio characteristics and strategies and common HRM practices and approaches. Such findings suggest an additional level of institutional assimilation and conformity amongst companies and their HRM practices within industries (Powell \& DiMaggio, 1991; Oliver, 1997). The findings suggest that strategic approaches used to manage human resources can be understood in relation to strategic groups functioning in an industry, not just at the firm or industry levels.

The second theme of strategic groups shaping SHRM practices and approaches raises important considerations for a more nuanced understanding of SHRM. The characteristics which help delineate the three strategic groups are familiar in strategic management, and specifically the best fit SHRM approach, as helping to determine people management approaches and practices (Boxall \& Purcell, 2008; 2003). For example, the international strategic orientations (Perlmutter, 1969) of the strategic groups as well as their predominant market entry modes, parent company interests and main strategic choices at corporate and business levels (Johnson et Scholes, 2005), highlight that the original best fit SHRM arguments for how people should be managed needs to challenged in relation to the opportunity they offer companies to differentiate themselves within certain industries. There is then value in exploring companies' corporate and business strategies at an industry level for a more fine grained understanding of how competition shapes people management strategies and practices. 
The cognitive approach to identifying strategic groups suggests that the insights of corporate executives into competition shape strategies and practices (Reger \& Huff, 1993; Peteraf \& Shanley, 1997; Panagiotou, 2006; 2007). In this study, the HR respondents mentioned their competitors when explaining their own organisation's responses to industry developments and ways of managing human resources. It is evident that what 'the others' are doing shapes the management of strategic human resources resulting in the detection of similar HRM practices within the three strategic groups in the international hotel industry. However, the implications of these common practices are less clear. There are positive and negative consequences of strategic group membership (Peteraf \& Shanley, 1997). The positive outcomes of strategic group membership include coordination effects (where there are interdependent benefits from members' actions); efficiency effects (where information exchange between members increases efficiencies and innovation); and reputation effects (where the identity of members helps to reduce search costs) (Peteraf \& Shanley; 1997). These outcomes need to be explored directly in HRM terms to see whether there are, for example, more movements of human resources between strategic group members, similar levels of adoption of HRM techniques and technologies, and similar employer reputations achieved within strategic groups. Conversely the negative consequences of strategic group identity are: "reduced flexibility, strategic myopia and suboptimizing behavior" (Peteraf \& Shanley, 1997 p. 180). Likewise, such obstructive rigidities and stagnant thinking and behaviour in HRM interventions, needs to be investigated in relation to the links between strategic groups and SHRM.

Another feature of strategic group research is the appearance of transient groups (Panagiotou, 2006), which are firms (Reger \& Huff, 1993 p.117) who "are changing from one strategic position to another, but along dimensions common to other firms in the industry." The Mixed Portfolio Purchasers strategic group is suggestive of just such a transient group, moving from the strategic position associated with Prestige Operators towards that of the Multi-branders. 
The mobility barriers associated with accessing new strategic groups are highlighted in the literature (McGee et al., 1995; Reger \& Huff, 1993) and appear evident in the HRM challenges and changing priorities the Mixed Portfolio Purchasers encountered as they attempted to realise the benefits of their newly enlarged organisations. The real difficulty in achieving the added value of their acquisitions, and subsequent moves to become international hotel operators of multiple brands, occurs where both Mixed Portfolio Purchasers were prey to hostile takeovers just after the research was completed. Transient groups also reflect the broader repositioning of an industry (Panagiotou, 2006; 2007) and subsequent moves in the international hotel industry support this suggestion as three of the eight firms have now secured membership of the Multibranders strategic group by moving along a similar strategic path to the Mixed Portfolio Purchasers, but with more success.

\section{Conclusions and Recommendations}

Within the SHRM literature the three main approaches (best practice, 'best fit' and RBV) have traditionally been seen as independently pursued by firms. However, more recent work has suggested that companies will simultaneously adopt variations of these approaches and so a combined view of SHRM is more appropriate and reflects the complex environments and competing perspectives companies face (Boxall \& Purcell, 2000; 2003; 2008). This study has focused on the strategic human resources and associated HRM strategies and practices in a global industry in order to explore how companies pursue competitive advantage in an industry. The literature has acknowledged that different industries experience institutional factors to varying extents (Boselie et al., 2002; 2003; Paauwe \& Boselie, 2002) and as such in some industries it may be that other institutional factors may take precedence over parent country aspects of influence. This study of the international hotel industry suggests this to be the case for strategic human resources, not only because of industry wide features, but also because of the prominence of strategic groups. This conclusion emerges amidst wider calls for 
HRM research focused more clearly on new institutionalism and the strategic balance theory (Boselie et al., 2009; Oliver, 1997), with levels of analysis stretching beyond the firm and industry dimensions.

In the last thirty years SHRM theoretical and empirical research has advanced through engagement with strategic management concepts and theories (Boxall \& Purcell, 2003; 2008; Storey, 1992). Within strategic management, strategic groups have been seen as way of understanding the competitive environments firms face within industries (Porter, 1980; McGee et al., 1995; Dranove et al., 1998) and has taken a prescriptive approach to determining firms' closest industry rivals. More recent studies of strategic groups have adopted a cognitive approach asking executives and strategists themselves to identify the strategic variables, which determine subsets of industry rivals (Reger \& Huff, 1993; Peteraf \& Shanley, 1997; Panagiotou, 2006; 2007). This research asked HRM executives about the approaches they took to managing their strategic human resources across their international hotel portfolios, and strategic groups emerged through the strategic variables and HRM practices used to manage HGMs as strategic human resources in the IHCs. Such evidence reinforces the (mobility) barriers companies need to overcome in their quest for competitive advantage through human resources and other strategic options. This link between SHRM approaches and strategic groups has not been identified previously and suggests several important routes for further investigation. Future research directions include longitudinal studies exploring the mobility of organisations between strategic groups and the mobility of human resources between organisations and strategic groups. Most significantly the emergence of strategic groups highlights another level of institutional fit with more pressures for conformance amongst organisations supposedly attempting to differentiate themselves from each other (Panagiotou, 2007). Managing these dualities of conformance and differentiation is challenging but as Boon et al. (2009) suggest not impossible with opportunities for innovative responses apparent. 
Above all these studies highlight that strategists (executives from all functions) may benefit from greater awareness of industry and strategic group pressures. If competitive advantage is achieved via differentiated and synergistic strategies and practices then such decision-makers should be encouraged to see beyond the conventional limitations of their industries and strategic groups. This may demand new priorities and ways of educating and developing strategic management skills and thinking in the strategic management and SHRM fields (Panagiotou, 2006; 2007).

The results and conclusions from this study do need to be considered alongside the limitations of the research where the perspectives of human resource executives and their teams were the prime focus. Finally, although the specific value of understanding competition within an international industry has been highlighted as a key feature throughout this article, it is important to acknowledge that other industries may provide different insights into strategic groups and HRM strategies and practices. 


\section{References:}

Adler, N. J. \& Ghadar, F. (1990), "Strategic Human Resource Management: A Global Perspective", Chapter in Pieper, R. (ed.) (1990), Human Resource Management in International Comparison, De Gruyter, Berlin/New York, pp. 235-260.

Bartlett, C. \& Ghoshal, S. (1989), Managing Across Borders: The Transnational Solution London, Hutchinson.

Bartlett, C. \& Ghoshal, S. (2000), Transnational Management, $3^{\text {rd }}$ edition, Irwin McGraw-Hill, Boston, MA.

Beals, P. (2006), "Hotel asset: management: will a North American phenomenon expand internationally?", Chapter 15 in Harris, P. \& Mongiello, M. (2006), Accounting and Financial Management: Developments in the International Hospitality Industry, Butterworth Heinemann, Oxford.

Becker, B.E. \& Huselid, M.A. (2006), "Strategic Human Resources Management: Where Do We Go From Here?”, Journal of Management, Vol. 32, pp.898-925.

Beer, M., Spector, B., Lawrence, P.R., Mills, D.Q. \& Walton, R.E. (1984), Managing Human Assets, Free Press; New York.

Bjorkman, I. (2006), "International human resource management research and institutional theory", Chapter 24 in Bjorkman, I. \& Stahl, G.K. (eds.) (2006), Handbook of Research in International Human Resource Management, Edward Elgar, Cheltenham, UK, pp. 463-474.

Bonache, J. \& Fernandez, Z. (1999), "Strategic staffing in multinational companies: a resource-based approach", Chapter 9 in Brewster, C. \& Harris, H. (eds.) (1999), International HRM: Contemporary Issues in Europe, London and New York, Routledge pp. 163-183.

Boon, C., Paauwe, J., Boselie, P. \& Den Hartog, D. (2009), "Institutional pressures and HRM: developing institutional fit", Personnel Review, Vol.38 No.5, pp.492-508.

Boselie, P., Brewster, C. \& Paauwe, J. (2009) "In search of balance - managing the dualities of HRM: an overview of the issues", (Guest editorial) Personnel Review, Vol.38, No.5, pp.461-471.

Boselie, P., Paauwe, J. \& Richardson, R. (2003), "Human Resource Management, institutionalization and organizational performance: a comparison of hospitals, hotels and local government", International Journal of Human Resource Management, Vol. 14 No. 8, December, pp. 1407-1429.

Boselie, P., Paauwe, J. \& Richardson, R. (2002), "Human Resource Management, Institutionalisation and Organisational Performance: a comparison of hospitals, hotels and local government", Erasmus Research Institute of Management Report Series Research in Management, downloaded $15^{\text {th }}$ January 2004 from www.erim.eur.nl

Boxall, P. (2003), "HR strategy and competitive advantage in the service sector", Human Resource Management Journal, Vol. 13 No. 3, pp. 5-20.

Boxall, P. \& Steeneveld, M. (1999), "Human Resource Strategy and Competitive Advantage: A Longitudinal Study of Engineering Consultancies", Journal of Management Studies, Vol. 36, No. 4, pp.443-463.

Boxall, P. \& Purcell, J. (2008), Strategy and Human Resource Management, $2^{\text {nd }}$ edition, Palgrave Macmillan, Basingstoke.

Boxall, P. \& Purcell, J. (2003), Strategy and Human Resource Management, Palgrave Macmillan, Basingstoke. 
Boxall, P. \& Purcell, J. (2000), "Strategic human resource management: where have we come from and where should we be going?", International Journal of Management Reviews, Vol. 2 No. 2, June, pp.183203.

Brewster, C. (2006), "Comparing HRM policies and practices across geographical borders", Chapter 5 in Stahl, G.K. \& Bjorkman, I. (eds.) (2006), Handbook of Research in International Human Resource Management, Edward Elgar, Cheltenham, UK; pp. 68-90.

Brewster, C. (1999), "Different Paradigms in Strategic HRM: Questions raised by comparative research", in Wright, P.M., Dyer, L.D., Boudreau, P. \& Milkovich, G.T. (1999), Research in Personnel and Human Resource Management: Strategic Human Resources Management in the Twenty-First Century Supplement 4, JAI Press; London England, pp. 213-238.

Brewster, C. (1991), The Management of Expatriates, Kogan Page, London.

Coller, X. \& Marginson, P. (1998), "Transnational management influence over changing employment practice: a case from the food industry", Industrial Relations Journal, Vol. 29 No. 1, pp. 4-17.

Curry, B. Davies, F. Phillips, P. Evans, M. \& Moutinho, L. (2001), "The Kohonen self-organizing map: an application to the study of strategic groups in the UK hotel industry", Expert Systems, Vol. 18 No. 1 pp.1931.

Delery, J.E. \& Doty, D.H. (1996), "Modes of Theorizing in strategic human resource management: tests of Universalistic, contingency and configurational performance predictions", Academy of Management Journal, Vol. 39, No. 4, pp. 802-835.

DiMaggio, P.J. \& Powell, W.W. (1983), "The iron cage revisited: institutional isomorphism and collective rationality in organizational fields", reprinted as Chapter 3 in Powell, W.W. \& DiMaggio, P.J. (1991), The new institutionalism in organizational analysis, The University of Chicago Press, Chicago/London.

Dranove, D. Peteraf, M. \& Shanley, M.( 1998), "Do Strategic groups exist? An Economic Framework for Analysis", Strategic Management Journal, Vol. 19, No. 11 pp.1029-1044.

Easterby-Smith, M., Malina, D. \& Yuan, L. (1995), "How culture sensitive is HRM? A comparative analysis of practice in Chinese and UK companies", International Journal of Human Resource Management, Vol. 6 No. 1, February, pp.31-59.

Edwards, P., \& Ferner, A. \& Sisson, K. (1996), "The conditions for international human resource management: two case studies", The International Journal of Human Resource Management, Vol. 7 No.1, pp. $20-40$.

Eyster, J.J. (1997), "Hotel Management Contracts in the U.S.”, Cornell Hotel \& Restaurant Administration Quarterly, June p.21- 33.

Ferguson, T.D., Deephouse, D.L. \& Ferguson, W.L. (2000), "Do Strategic Groups differ in reputation?", Strategic Management Journal, Vol. 21, pp. 1195-1214.

Ferner, A. (1997), "Country of Origin effects and HRM in multinational companies", Human Resource Management Journal, Vol. 7 No. 1, pp. 19-37.

Ferner, A. (1994), "Multinational companies and human resource management: an overview of research issues", Human Resource Management Journal, Vol. 4 No. 2, pp. 79-102. 
Ferner, A. \& Quintanilla, J. (1998), "Multinationals, business systems and HRM: the enduring influence of national identity or a process of Anglo-Saxonization", International Journal of Human Resource Management, Vol. 9 No. 4, August, pp. 710-731.

Fombrun, C., Tichy, N.M. \& Devanna, M.A. (eds.) (1984), Strategic Human Resource Management, New York; Wiley.

Forte, C. (1986), Forte: The Autobiography of Charles Forte, Sidgwick and Jackson, London.

Gannon, J.M., Roper, A.J.\& Doherty, J. (2010), "The impact of hotel management contracting on IHRM practices: Understanding the bricks and brains split", International Journal of Contemporary Hospitality Management, Vol. 22 No. 5, pp.638 - 658.

Guest, D. (1989), “HRM: implications for industrial relations", in Storey, J.(1989), New Perspectives on Human Resource Management, Routledge, London.

Guilding, C. (2006), "Investment appraisal issues arising in hotels governed by a management contract", Chapter 20 in Harris, P. \& Mongiello, M. (2006), Accounting and Financial Management: Developments in the International Hospitality Industry, Butterworth Heinemann, Oxford.

Hannon, J.M., Huang, I. \& Jaw, B. (1995), "International Human Resource Strategy and Its Determinants: The case of subsidiaries in Taiwan", Journal of International Business Studies, Vol. 26, No. 3 pp.531-554.

Harvey, M.G., Novicevic, M.M. \& Speier, C. (1999), "Inpatriate Managers: How to increase the probability of Success”, Human Resource Management Review, Vol. 9 No. 1, pp51-81.

Harvey, M.G., Novicevic, M.M. \& Speier, C. (2000), "Strategic Global Human Resource Management: The role of Inpatriate Managers", Human Resource Management Review, Vol. 10 No. 2, pp.153-175.

Heenan, D.A. \& Perlmutter, H.V. (1979), Multinational Organization Development, Addison-Wesley, Reading, M.A.

Hendry, C. \& Pettigrew, A. (1986), "The Practice of Strategic Human Resource Management", Personnel Review, Vol. 15 No. 3, pp. 3-8.

Huselid, M. (1995), "The impact of human resource management practices on turnover, productivity and corporate financial performance", Academy of Management Journal, Vol.38 No.3, pp.635-72.

Johnson, G. \& Scholes, K. (2005), Exploring Corporate Strategy: Text and Cases, Pearson education, Harlow.

Kamoche, K.N. (2001), Understanding Human Resource Management, , Open University Press, Buckingham.

Kriegl, U. (2000), "International hospitality management", Cornell Hotel and Restaurant Administration Quarterly, April, Vol. 41 No.2 pp.64-71.

Ladkin, A. \& Juwaheer, T.D. (2000), "The career paths of hotel general managers in Mauritius", International Journal of Contemporary Hospitality Management, Vol. 12 No. 2, pp.119-125.

Leask, G. and Parker, D. (2006), "Strategic groups theory, review, examination and application in the UK pharmaceutical industry", Journal of Management Development, Vol. 24 No. 4 pp. 386-408.

Leonard-Barton, D. (1995), “Wellsprings of Knowledge: Building and Sustaining the Sources of Innovation”, Harvard Business School Press; Boston, Masachusetts. 
Litteljohn, D. (2003), "Hotels" Chapter 1 in Brotherton, B. (ed.) (2003), The International Hospitality Industry: Structure, Characteristics and Issues, Oxford, UK Butterworth-Heinemann, pp. 5-29.

Litteljohn, D. (1999), "Industry structure and strategic groups", Chapter 23 in Brotherton, B. (ed.) The Handbook of Contemporary Hospitality Management Research, Chichester, John Wiley \& Sons, pp. 455475.

Litteljohn, D., Roper, A.J. \& Altinay, L. (2007), "Territories still to find - the business of hotel internationalisation”, International Journal of Service Industry Management, Vol. 18 No. 2, pp.167-183.

Marchington, M., Carroll, M. \& Boxall, P. (2003), "Labour scarcity, the resource-based view, and the survival of the small firm: a study at the margins of the UK road haulage industry", Human Resource Management Journal, Vol. 13 No. 4, pp. 5-22.

Marchington, M. \& Grugulis, I. (2000), "Best practice' human resource management: perfect opportunity or dangerous illusion", International Journal of Human Resource Management, Vol. 11 No. 6, pp.11041124.

McGee, J. Thomas, H. \& Pruett, M. (1995), "Strategic groups and the Analysis of Market Structure and Industry Dynamics", British Journal of Management, Vol. 6, pp.257-270.

Miles, M.B. \& Huberman, A.M. (1994), Qualitative Data Analysis: an expanded sourcebook, Thousand Oaks, California; Sage.

Miles, R.E. \& Snow, C.C. (1984), "Designing Strategic Human Resource Systems", Organizational Dynamics, Summer Vol. 13 No. 1, pp. 36-52.

Morris, S.S., Snell, S.A. \& Wright, P.M. (2006), "A resource-based view of international human resources: towards a framework of integrative and creative capabilities", in Chapter 22 of Stahl, G.K. \& Bjorkman, I. (eds.) (2006), Handbook of Research in International Human Resource Management, Cheltenham, UK; Edward Elgar, pp. 433-448.

Mueller, F. (1996), "Human Resources as strategic assets: an evolutionary resource-based theory", Journal of Management Studies, Vol. 33 No. 6, pp.757-785.

Newman, K. L. \& Nollen, S.D. (1996), "Culture and Congruence: the Fit between management practices and national culture", Journal of International Business Studies, $4^{\text {th }}$ quarter, pp. 753-779.

Nickson, D.P. (1999), A Study of the Internationalisation Strategies of Three Hotel Companies, with a particular focus on Human Resource Management, doctoral thesis submitted to the University of Strathclyde.

Nickson, D. (1998), “A Review of Hotel Internationalisation with a Particular Focus on the Key Role Played by American Organisations", Progress in Tourism \& Hospitality Research, Vol. 4 pp. 53-66.

Oliver, C. (1997), "Sustainable Competitive Advantage: Combining Institutional and Resource-based views", Strategic Management Journal, Vol. 18 No. 9, pp. 697-17.

Paauwe, J. (2008), "HRM and Performance: In Search of Balance", paper presented at the British Academy of Management Special Interest Group on HRM conference, April, Kingston University, UK.

Pauuwe, J. \& Boselie, P. (2008), “HRM and Performance: What's Next?", Centre for Advanced Human Resource Studies (CAHRS), Cornell University. 
Paauwe, J. \& Boselie, P. (2003), "Challenging 'strategic HRM' and the relevance of the institutional setting”, Human Resource Management Journal, Vol. 13 No. 3, pp. 56-70.

Panagiotou, G. (2008), "Conjoining prescriptive and descriptive approaches: Towards an integrative framework of decision making: A conceptual note", Management Decision, Vol. 46 No. 4, p.553-564.

Panagiotou, G. (2007), "Reference theory: strategic groups and competitive benchmarking", Management Decision, Vol. 45 No. 10, pp. 1595-1621.

Panagiotou, G. (2006), "Managerial cognitions of competitive environments: a strategic group analysis", Management Research News, Vol. 29 No. 7, pp. 439-456.

Perlmutter, H.V. (1969), "The Tortuous Evolution of the Multinational Company", Columbia Journal of World Business, Jan/Feb, pp.9-18.

Peteraf, M. \& Shanley, M. (1997), "Getting to Know You: A Theory of Strategic Group Identity", Strategic Management Journal, Vol. 18 Summer Special Issue: Organizational and Competitive Interactions, pp. 165-186.

Pfeffer, J. (1998), The Human Equation: Building Profits by Putting People First, Boston, MA: Harvard Business School Press.

Pfeffer, J. (1994), Competitive Advantage through People, Boston, MA: Harvard Business School Press.

Porter, M.E. (1980), Competitive Strategy: Techniques for Analyzing Industries and Competitors, New York, The Free Press.

Powell, W.W. \& DiMaggio, P.J. (1991), The new institutionalism in organizational analysis, Chicago/London, The University of Chicago Press.

Prahalad, C.K. \& Hamel, G., (1990), "The Core Competencies of the Organization”, Harvard Business Review, May-June, pp.79-91.

Purcell, J. (2001), "The Meaning of Strategy in HRM", Chapter 4 in Storey, J. (ed.) (2001), Human Resource Management: a critical text, $2^{\text {nd }}$ edition, London, International Thomson Business Press, pp.5977.

Purcell, J. (1999), "Best practice and best fit: chimera or cul de sac?", Human Resource Management Journal, Vol. 9 No.3, pp.26-41.

Reger, R. \& Huff, A.S. (1993), "Strategic groups: a cognitive perspective”, Strategic Management Journal, Vol. 14 No. 2, pp. 103-124.

Robson, C., (2002) Real World Research, (2 ${ }^{\text {nd }}$ ed.) Oxford; Blackwell Publishing.

Roper, A., (1995), "The emergence of hotel consortia as transorganizational forms", International Journal of Contemporary Hospitality Management, Vol. 7 No. 1, pp.4-9.

Roper, A., Doherty, L., Brookes, M. \& Hampton, A. (2001), "Company Man meets International Customer", Chapter 2 in Guerrier, Y. \& Roper, A. (2001), A Decade of Hospitality Management Research: Tenth Anniversary Volume, CHME Threshold Press, pp. 14-36.

Ropeter, J.C., \& Kleiner, B.H., (1997) "Practices of excellent companies in the hotel industry", Managing Service Quality, Vol. 7 No.3, pp.132-135. 
Rosenzweig, P.M. (2006), “The dual logics behind international human resource management: pressures for global integration and local responsiveness", Chapter 3 in Stahl, G.K. \& Bjorkman, I. (eds.) (2006), Handbook of Research in International Human Resource Management, Cheltenham, UK; Edward Elgar, pp.36-48.

Rosenzweig, P.M. \& Nohria, N. (1994), "Influences on Human Resource Management Practices in Multinational Corporations", International Journal of Business Studies, Vol. 25 pp.229-251.

Sanz-Valle, R., Sabater-Sanchez, R. \& Aragon-Sanchez, A. (1999), "Human Resource management and business strategy links: an empirical study", International Journal of Human Resource Management, Vol. 10, No. 4 August pp.655-671.

Saunders, M., Lewis, P., \& Thornhill, A., (2000), Research Methods for Business Students, $2^{\text {nd }}$ edition Harlow; Financial Times, Prentice-Hall.

Schuler, R.S., \& Jackson S.E., (2007), (eds.) Strategic Human Resource Management: A Reader, London: Blackwell Publishers.

Schuler, R. \& Jackson, S. (1987), "Linking competitive strategy and human resource management practices", Academy of Management Executive, Vol. 3 No.1, pp.207-219.

Scullion, H. \& Starkey, K. (2000), "In search of the changing role of the corporate human resource function in the international firm", International Journal of Human Resource Management, Vol. 11 No. 6, December, pp. 1061-1081.

Short, J.C., Ketchen, D.J., Palmer, T.B. \& Hult, G.T.M. (2007), "Firm, Strategic Group, and Industry Influences on Performance", Strategic Management Journal, Vol. 28, p. 147-167.

Silverman, D. (1999), Doing Qualitative Research: A Practical Handbook, Sage Publications, London.

Silverman, D. (1997), "Introducing Qualitative Research", Chapter 1 in Silverman, D. (ed.) (1997), Qualitative Research: Theory, Method and Practice, Sage, London, pp. 1-8.

Sorge, A. (2004), "Cross-National Differences in Human Resources and Organization", Chapter 5 in Harzing, A. \& Van Ruysseveldt, J. (eds.) International Human Resource Management, $2^{\text {nd }}$ edition, London, Sage pp.117-140.

Sparrow, P., Brewster, C. \& Harris, H. (2004), Globalizing Human Resource Management, Routledge and CIPD, London.

Storey, J., (1992), Developments in the management of human resources: an analytical review, Oxford, Blackwell.

Taylor, S., Beechler, S. \& Napier, N. (1996), “Toward an Integrative Model of Strategic International Human Resource Management”, Academy of Management Review, Vol. 21 No. 4, pp. 959-985.

Thompson, P., Nickson, D., Wallace, T. \& Jones, C. (1998), "Internationalisation and Integration: A Comparison of Manufacturing and Service Firms", Competition and Change, Vol. 3 pp.387-415.

Tyson, S. \& Parry, E. (2008), "The Need for analysis at the sectoral level in HRM Research theoretical and methodological implications", paper presented at the British Academy of Management Special Interest Group on HRM conference, April, Kingston University, UK.

Whitla, P., Walters, P.G.P. \& Davies, H. (2007), "Global strategies in the international hotel industry", International Journal of Hospitality Management, Vol. 26 pp. 777-792. 
Wright, P.M., Dunford, B.B. \& Snell, S.A. (2004), "Human Resources and the Resource Based view of the Firm", $12^{\text {th }}$ January, downloaded on $15^{\text {th }}$ January 2004

http://www.acc.ntu.edu.tw/ workshop/Reading\%20List/Patrick\%20Wright/HR\%20and\%20RBV.pap.d $\underline{\mathrm{oc}}$

Wright, P.M., McMahan, G.C. \& McWilliams, A. (1994), "Human Resources and Sustained Competitive Advantage: A Resource-based perspective", International Journal of Human Resource Management, Vol. 5 No. 2, pp.301-326.

Wright, P.M. \& Snell, S. (1998), "Toward a unifying framework for exploring fit and flexibility in strategic human resource management", Academy of Management Review, Vol. 23 No. 4, pp.756-772. 
Figure 1. The Initial Focus of SIHRM approaches

\begin{tabular}{|l|c|c|}
\hline SIHRM approaches & Primary Focus & Level \\
\hline $\begin{array}{l}\text { Resource based view (RBV) } \\
\text { Competitive advantage achieved through } \\
\text { developing resources which are Valuable, } \\
\text { Rare, Inimitable, Non-substitutable and Rent } \\
\text { achieving }\end{array}$ & Internal & Company/firm \\
\hline $\begin{array}{l}\text { Best Fit onsed on crafting HRM practices tied to } \\
\text { strategic management models - typically } \\
\text { through strategic analyses tools of market } \\
\text { position }\end{array}$ & External \\
$\begin{array}{l}\text { Based upon aligning HRM practices to } \\
\text { different international and domestic cultural } \\
\text { and institutional contexts and company } \\
\text { demand for standardisation }\end{array}$ & Nompetitive market \\
\hline $\begin{array}{l}\text { Best Practice } \\
\text { Originally identified as sophisticated practices } \\
\text { capable of achieving competitive advantage. } \\
\begin{array}{l}\text { Now associated with HRM practices which are } \\
\text { table stakes' essential for operating with } \\
\text { social legitimacy within an industry }\end{array}\end{array}$ & market \\
\hline
\end{tabular}


Table 1. Profiles of Global Hotel Companies in sample

\begin{tabular}{|c|c|c|c|c|}
\hline $\begin{array}{l}\text { International } \\
\text { Hotel companies }\end{array}$ & $\begin{array}{l}\text { No. of } \\
\text { hotels }\end{array}$ & Brands & $\begin{array}{l}\text { No. of } \\
\text { countries }\end{array}$ & Suggested Strategy and Methods of Growth \\
\hline $\begin{array}{l}\text { Anglo-American } \\
\text { Premium }\end{array}$ & $150+$ & $\begin{array}{l}\text { - Prestige international brand } \\
\text { - National UK mid-market } \\
\text { brand }\end{array}$ & 48 & $\begin{array}{l}\text { Differentiation strategies - based upon the power of the company's hotel brand name. Expansion in prime city } \\
\text { centre and resort locations and the development of hotel clusters in countries or regions achieved through } \\
\text { management contracts and joint ventures. }\end{array}$ \\
\hline Britbuyer & 900 & $\begin{array}{l}\text { Nine brands at international } \\
\text { and domestic levels } \\
\text { - Upscale } \\
\text { - Mid market } \\
\text { - Budget }\end{array}$ & 50 & $\begin{array}{l}\text { Various strategies deployed at the different market levels. Budget brands operate on a no frills strategy. } \\
\text { International luxury properties follow a differentiation (premium price) strategy. One third of properties are } \\
\text { owned and two-thirds are management contract arrangements. Growth through management contracting, } \\
\text { franchising or marketing agreements and some ownership. }\end{array}$ \\
\hline $\begin{array}{l}\text { Contractman } \\
\text { International }\end{array}$ & 200 & Four luxury or upscale brands & 35 & $\begin{array}{l}\text { Focused differentiation strategy based upon distinctive design and architectural features associated with } \\
\text { properties and attention to detail service style. Grows solely by securing management contract agreements } \\
\text { with select investors. }\end{array}$ \\
\hline Euroalliance & $50 *$ & - $\quad$ One upscale brand & 16 & $\begin{array}{l}\text { Differentiation strategy based upon developing modern and efficient first class hotels. Growth achieved } \\
\text { through management contracting, rather than ownership, and a global partnership with one of America's } \\
\text { largest international hotel corporations. }\end{array}$ \\
\hline Euromultigrow & $2,500+$ & $\begin{array}{l}\text { Seventeen brands split into: } \\
\text { - Upscale \& midscale } \\
\text { - Economy \& budget } \\
\text { - Leisure hotels }\end{array}$ & 73 & $\begin{array}{l}\text { Operates at different market levels - particularly concerned with distinctiveness and value for money and } \\
\text { therefore a broad hybrid strategy is identified. } \\
\text { Mixed type of operation is used across portfolio; approximately } 46 \% \text { owned, } 21 \% \text { leased, } 22.5 \% \text { management } \\
\text { contracts and } 10.5 \% \text { franchised. }\end{array}$ \\
\hline FranchiseKing & $2,300+$ & $\begin{array}{l}\text { Five brands: } \\
\text { - } 2 \text { at mid market } \\
\text { - Prestige brand } \\
\text { - Budget brand } \\
\text { - Holiday resorts }\end{array}$ & 63 & $\begin{array}{l}\text { Hybrid strategy based upon presence across a range of market sectors but competitively priced in each sector. } \\
\text { Company documentation states the aim as "To be the preferred hotel system, hotel management company, } \\
\text { and lodging franchise in the world. To build on the strength of the FranchiseKing name utilising quality and } \\
\text { consistency as the vehicle to enhance it's perceived "value for money" position in the middle market." }\end{array}$ \\
\hline Globalalliance & 190 & $\begin{array}{ll}- & \text { Prestige brand } \\
\text { - } & \text { Mid-market brand - } \\
& \text { North America }\end{array}$ & 70 & $\begin{array}{l}\text { Focused differentiation strategy based upon international exposure and expertise in the luxury hotel market. } \\
\text { Growth through management contracting, franchising or marketing agreements and some ownership. }\end{array}$ \\
\hline USBonusbrand* & 700 & $\begin{array}{l}\text { Seven brands: } \\
\text { - } 2 \text { at both mid market and } \\
\quad \text { budget levels } \\
\text { - Prestige brand } \\
\text { - Suites } \\
\text { - Holiday resorts }\end{array}$ & 35 & $\begin{array}{l}\text { Deploys several strategies including a hybrid strategy for its domestic units and a differentiation (with } \\
\text { premium price) strategy for most of its international properties at the prestige level. Growth through } \\
\text { management contracting and franchising, with limited ownership. } \\
\text { *This company did not participate in the final stages of the research }\end{array}$ \\
\hline USmixedeconomy & 460 & $\begin{array}{l}\text { - } \text { Prestige brand } \\
\text { Mid-market brand - North } \\
\text { America }\end{array}$ & 63 & $\begin{array}{l}\text { Adopts a variety of strategies including a hybrid strategy for its domestic units and a differentiation (with } \\
\text { premium price) strategy for most of its international properties. Growth through management contracting } \\
\text { some ownership and franchising. }\end{array}$ \\
\hline
\end{tabular}


Table 2. International Hotel Company Strategic Groups

\begin{tabular}{|c|c|c|}
\hline & Similarities & Differences \\
\hline $\begin{array}{l}\text { Strategic Group } 1 \text { - } \\
\text { The Multi- } \\
\text { branders } \\
\text { (two companies) } \\
\text { FranchiseKing and } \\
\text { Euromultigrow }\end{array}$ & $\begin{array}{ll}\text { - } & \text { Parent companies - Related horizontally } \\
\text { diversified } \\
\text { - } & \text { Large size - 2000+ hotels } \\
\text { - } & \text { High levels of internationalisation but } \\
\text { - } & \text { Multiple brands (luxury to budget) } \\
\text { - } & \text { Difficulties aligning parent company, } \\
\text { - } & \text { brand names and operations } \\
\text { - } & \text { Range of market entry modes } \\
\text { - } & \text { Ethnocentric orientation } \\
\text { - } & \text { Global organisation } \\
\end{array}$ & $\begin{array}{l}\text { National cultural origins } \\
\text { Mid-market brand dominates in } \\
\text { one company whilst distinct } \\
\text { brands used for different market } \\
\text { segments by other } \\
\text { One company uses more } \\
\text { franchising }\end{array}$ \\
\hline
\end{tabular}

\begin{tabular}{|c|c|c|}
\hline $\begin{array}{l}\text { Strategic Group 2- } \\
\text { The Mixed } \\
\text { Portfolio } \\
\text { Purchasers } \\
\text { (two companies) } \\
\text { Britbuyer and } \\
\text { USmixedeconomy }\end{array}$ & $\begin{array}{ll}\text { - } & \text { Similar size (between } 400 \text { and } 1,000 \\
\text { - } & \text { Motels) } \\
\text { - } & \text { Strong domestic presence and distinctive } \\
\text { international operations } \\
\text { - } \quad \text { Range of market entry modes } \\
\text { - } \text { Acquisitive growth of European prestige } \\
\text { brands } \\
\text { - } \quad \text { Brands offered at similar market levels } \\
\text { - } \text { and international portfolios, corporate } \\
\text { - } \quad \text { Ethategies and new acquisitions } \\
\text { geocentric aspirations } \\
\text { Multinational organisation }\end{array}$ & $\begin{array}{l}\text { One company has more } \\
\text { ownership/partial ownership of } \\
\text { hotels } \\
\text { One company has much smaller } \\
\text { budget brand domestic interests }\end{array}$ \\
\hline
\end{tabular}

\begin{tabular}{|c|c|c|}
\hline $\begin{array}{l}\text { Strategic Group } 3 \text { - } \\
\text { The Prestige } \\
\text { Operators } \\
\text { (four companies) } \\
\text { Anglo-American } \\
\text { Premium, } \\
\text { Contractman } \\
\text { International, and } \\
\text { Euroalliance } \\
\text { Globalalliance }\end{array}$ & $\begin{array}{ll}\text { - } & \text { Parent companies - Related diversified } \\
\text { - } & \text { Similar Size (between } 50 \text { and } 202 \text { hotels) } \\
\text { - } & \text { Similar levels of low internationalisation } \\
\text { - } & \text { Focus upon luxury, first class hotel market } \\
\text { (resort and business) } \\
\text { - } \\
\text { Strategies broadly differentiation and } \\
\text { focused differentiation } \\
\text { - } \text { Growth primarily through management } \\
\text { - contracting } \\
\text { Broadly geocentric but with some aspects } \\
\text { of ethnocentrism } \\
\text { Transnational organisation }\end{array}$ & $\begin{array}{l}\text { Two companies have separate } \\
\text { domestic operations } \\
\text { Two companies have grown } \\
\text { through strategic partnerships }\end{array}$ \\
\hline
\end{tabular}


Table 3 Responses from HR Executives from the Strategic Groups

\begin{tabular}{|c|c|c|c|}
\hline & Multibranders & Mixed Portfolio Purchasers & Prestige Operators \\
\hline $\begin{array}{c}\text { (1) the levels } \\
\text { of focus for } \\
\text { HRM }\end{array}$ & $\begin{array}{l}\text { "Our area, regional human resource } \\
\text { executives run national versions of our } \\
\text { company University training and } \\
\text { recruitment programmes to fit with } \\
\text { national vocational education." } \\
\text { Assistant HR director for Euromultigrow } \\
\text { EAME } \\
\text { "We have a critical mass of hotels in } \\
\text { certain countries and have built real } \\
\text { presence so we need to adopt some of } \\
\text { their practices as long as they fit now with } \\
\text { our competences." Corporate Training \& } \\
\text { Development Director FranchiseKing }\end{array}$ & $\begin{array}{l}\text { "Some areas, with more hotels, have a little bit } \\
\text { more autonomy than others and we have them do } \\
\text { their own management recruitment and training, } \\
\text { based on our head-office materials." Vice } \\
\text { President HR USmixedeconomy } \\
\text { "In France, Germany, the UK and the Benelux } \\
\text { and Scandinavian countries, where we have } \\
\text { critical mass, they have some flexibility for } \\
\text { recruitment and training. It has been a bit of a } \\
\text { struggle with our acquisition of M to get this } \\
\text { right, though." Britbuyer HR EAME director }\end{array}$ & $\begin{array}{l}\text { "We run a graduate management programme to ensure we have our next } \\
\text { crop of managers waiting in the wings. We also have an executive } \\
\text { management programme which includes an MBA - both are designed to } \\
\text { get us the GMs of the future." Corporate Director of Human Resources } \\
\text { Globalalliance } \\
\text { "Our graduate management programme is being revitalised for next year } \\
\text { and we'll be targeting the brightest from the hotel schools in Holland and } \\
\text { Switzerland for EAME. All our graduates must have language skills and } \\
\text { meet specific knowledge requirements." Anglo-American Premium Vice } \\
\text { President of HRs } \\
\text { I don't think graduate management schemes per se work. Instead we } \\
\text { recruit graduates, mainly from Switzerland and the Dutch schools, into } \\
\text { real jobs and although they're a hotel resource, we (headquarters) } \\
\text { monitor their progress and target them with specific courses to try and } \\
\text { bring them on." HR Vice President Euroalliance }\end{array}$ \\
\hline $\begin{array}{l}\text { (2) views } \\
\text { about } \\
\text { management } \\
\text { skills and } \\
\text { transferability } \\
\text { across brands }\end{array}$ & $\begin{array}{l}\text { "No, not so many people transferred. It } \\
\text { was quite common between one brand } \\
\text { and also quite common between } \\
\text { (names two other company brands at } \\
\text { the same market level) but not at all } \\
\text { between the others. It was difficult, not } \\
\text { good. Now we will have a stronger } \\
\text { parent company from this new } \\
\text { structure." HR Vice President for } \\
\text { Euromultigrow } \\
\text { "We have been training them in the use } \\
\text { of behavioural event interviewing to help } \\
\text { them, ... to spot the competencies. This } \\
\text { allows us to see where in the portfolio of } \\
\text { brands they can move to" Corporate } \\
\text { Training \& Development Director } \\
\text { FranchiseKing }\end{array}$ & $\begin{array}{l}\text { "We had to respect what was there. The } \\
\text { predominant national culture of the newly } \\
\text { acquired company) meant that we had a lot of } \\
\text { communicating and educating to do within our } \\
\text { company and within theirs. We moved managers } \\
\text { within (names the acquired company) between } \\
\text { units to give them a fresh start and many of them } \\
\text { are still with us. It worked out well really." } \\
\text { Regional HR director USmixedeconomy } \\
\text { "When we acquired company [M] there was a } \\
\text { bit of a standoff basically because they wanted to } \\
\text { be acquired by somebody else. ... It didn't help } \\
\text { that the CEO of our company went 'round their } \\
\text { hotels saying 'get rid of this' or 'do that'. Things } \\
\text { have changed now, again. There's more } \\
\text { appreciation of what [acquired company] does } \\
\text { right on the international scene and we're a lot } \\
\text { more open to learning from them. It's now two- } \\
\text { way." Britbuyer HR EAME director }\end{array}$ & $\begin{array}{l}\text { GMs skills needs "fall into four skill sets which ... one is managing } \\
\text { myself based on the premise that if I can't manage myself then I can't } \\
\text { really manage anybody else. Then managing others and then the third } \\
\text { one is problem solving and decision making and the fourth one is pro- } \\
\text { active achievement. Very difficult to measure, but the actual achievement } \\
\text { levels and the go for it and taking that extra risk, the entrepreneurial } \\
\text { part. And then there is the languages and cultural bit." HR Vice } \\
\text { President Euroalliance } \\
\text { "It feels it is difficult to see where a young manager's next move is in an } \\
\text { international company without the right language skills to allow widening } \\
\text { of transfer options."Anglo-American Premium Vice President of HRs } \\
\text { "There are core or critical parts to our business; marketing and sales, } \\
\text { managing human resources, financial management, creative decision- } \\
\text { making and leadership. These need to be displayed across cultures across } \\
\text { properties to make it as a GM." Vice President HR Contractman } \\
\text { International }\end{array}$ \\
\hline $\begin{array}{c}\text { (3) how } \\
\text { international } \\
\text { and domestic } \\
\text { operations } \\
\text { function }\end{array}$ & $\begin{array}{l}\text { "Most of these potential GMs do tend } \\
\text { still to be the same nationality as the } \\
\text { company, but I don't know why. We } \\
\text { don't necessarily want that, at all." } \\
\text { HR Vice President for Euromultigrow } \\
\text { "All GMs are informed that the best way } \\
\text { to read and become familiar with the }\end{array}$ & $\begin{array}{l}\text { 'For an international GM you need languages } \\
\text { and international experience - that is why some } \\
\text { managers from brands back home don't make it' } \\
\text { Vice President HR USmixedeconomy } \\
\\
\text { "Our domestic brand managers aren't our } \\
\text { international mangers. There is no transfer, } \\
\text { well ok I can think of one or two. You need }\end{array}$ & $\begin{array}{l}\text { "Why the four different parts of the world? Well each one has some } \\
\text { strengths. I mean that States you take marketing and very different human } \\
\text { resources. Asia you still have the luxury of being able to have a lot of } \\
\text { employees and a far bigger budget because costs are lower. Japan } \\
\text { because the way, the mentality of the Japanese market and customer is } \\
\text { different, and Europe to do same thing but with a very tight budget } \\
\text { because costs are so high." Vice President HR EAME Contractman } \\
\text { International }\end{array}$ \\
\hline
\end{tabular}




\begin{tabular}{|c|c|c|c|}
\hline & $\begin{array}{l}\text { (competency) guide is to read the } \\
\text { English version first - this is the } \\
\text { authoritative version." Corporate } \\
\text { Training \& Development Director } \\
\text { FranchiseKing }\end{array}$ & $\begin{array}{l}\text { international experience which creates a bit of a } \\
\text { catch } 22 \text { - because it is the old thing of 'you } \\
\text { can't get the job without the experience and you } \\
\text { can't get the experience without the job'." } \\
\text { Britbuyer HR EAME director }\end{array}$ & $\begin{array}{l}\text { "A future GM must have worked outside his or her home country before } \\
\text { they can be promoted to this level. It is important for managers to have } \\
\text { language skills not only to help them operate in particular locations but } \\
\text { also because there are far more career opportunities for those individuals } \\
\text { who can demonstrate language proficiency. Transfers are then an } \\
\text { important aspect of developing a career." Anglo-American Premium } \\
\text { Vice President of HRs }\end{array}$ \\
\hline $\begin{array}{l}\text { (4) extent of } \\
\text { owner } \\
\text { influence and } \\
\text { cultural } \\
\text { differences }\end{array}$ & $\begin{array}{l}\text { "Well most of the time, it depends on the } \\
\text { case of course, most of the time, the } \\
\text { shareholder of the hotel will be an } \\
\text { investor but he will not be an } \\
\text { operational actor. He is interested in the } \\
\text { bottom line, not what goes on inside the } \\
\text { hotel." HR Vice President for } \\
\text { Euromultigrow } \\
\text { "Owner interference depends on our } \\
\text { brands, the more exclusive the brand the } \\
\text { more influence but mainly we propose } \\
\text { people - 'this candidate has our firm } \\
\text { support'. Obviously the quality of the } \\
\text { relationship with the owner is very } \\
\text { important and you must respect their } \\
\text { wishes pertaining to GMs but it doesn't } \\
\text { cause us much trouble really." Vice } \\
\text { President for HR FranchiseKing }\end{array}$ & $\begin{array}{l}\text { We have owners, for example, ... but we have } \\
\text { owners who are very, very clear about the } \\
\text { people who we are likely, or more often than } \\
\text { not, we can't employ. Usually it's in terms of } \\
\text { nationalities and colours, race and sexual } \\
\text { preferences they don't like. It is their hotel and } \\
\text { if they say "I don't want somebody with red } \\
\text { hair" then you don't put somebody with red } \\
\text { hair in, it's as simple as that. Britbuyer HR } \\
\text { EAME director } \\
\text { "The frequency of moves our managers make are } \\
\text { also driven by how tightly an owner wants to } \\
\text { hang on to them. So we're constrained by } \\
\text { hardship factors, and owner's predilections and } \\
\text { preferences." Regional HR director } \\
\text { USmixedeconomy }\end{array}$ & $\begin{array}{l}\text { "Usually owners interview the three candidates we put forward for each } \\
\text { GM position and invariably, well they select the candidate preferred by } \\
\text { the company, though Vice Presidents often have to use some powers of } \\
\text { persuasion." Anglo-American Premium Vice President of HRs } \\
\text { "We have to know our owners really well to give them the GMs they want } \\
\text { and need. That's a tough call when you're growing so much." Vice } \\
\text { President HR Contractman International } \\
\text { "Some owners are really difficult and have to be managed carefully. } \\
\text { That's where our Regional guys come in. Others are great and they are } \\
\text { our business partners, with us for the long haul." HR Vice President } \\
\text { Euroalliance } \\
\text { "Owners do have a lot of influence because if we give them somebody } \\
\text { and they say 'we don't think this guy's any good', well! Although we } \\
\text { could force them upon them it isn't a very sensible thing to do. So the } \\
\text { owning company does have a big bearing on the GM slot." Corporate } \\
\text { Director of Human Resources Globalliance }\end{array}$ \\
\hline $\begin{array}{l}\text { (5) how and } \\
\text { where } \\
\text { managerial } \\
\text { talent is found }\end{array}$ & $\begin{array}{l}\text { "We have our area, regional human } \\
\text { resource people help our GMs identify } \\
\text { their managers who might one day make } \\
\text { it, who have the potential to be GMs too. } \\
\text { The area human resource people then } \\
\text { run some courses and do the training we } \\
\text { have developed through our company } \\
\text { University." HR Vice President for } \\
\text { Euromultigrow } \\
\text { "Some of our approach to identifying } \\
\text { GM potential is systematic, some is } \\
\text { opportunistic. We re trying to become } \\
\text { more systematic, through the new } \\
\text { competencies process. We've recognised } \\
\text { we have to have more local nationals } \\
\text { and fewer expatriates." Corporate } \\
\text { Training \& Development Director }\end{array}$ & $\begin{array}{l}\text { "I mean I am very conscious from this } \\
\text { conversation we are not doing all we could to } \\
\text { develop the next generation of GMs. It is partly } \\
\text { because the number two position in some units } \\
\text { has disappeared. So there aren't enough } \\
\text { opportunities for heads of departments to move } \\
\text { on and develop their experience. We haven't } \\
\text { had a problem so far but as we increase (grow) } \\
\text { we might be struggling for the right calibre of } \\
\text { GMs in a few years time." Britbuyer HR } \\
\text { EAME director } \\
\text { "You must realise that traditionally we have } \\
\text { consciously developed very good resident } \\
\text { managers/EAMs (Executive Assistant Managers) } \\
\text { so when these individuals took over their own } \\
\text { units there was a very low risk of failure. Since } \\
\text { our purchases and down-sizing, however, there } \\
\text { are now some properties that no longer have a }\end{array}$ & $\begin{array}{l}\text { "How do we manage our GMs? Well we include all managers here -well } \\
\text { it's a very integrated approach to career development, or management } \\
\text { development and the annual appraisal and it all comes together with } \\
\text { succession planning and the work we co-ordinate here (gestures to the } \\
\text { corporate head-office)." Corporate Director of Human Resources } \\
\text { Globalalliance } \\
\text { "We're [the executive team] in the hotels a lot, and the President was } \\
\text { really great, yesterday he was saying 'You know everybody whether } \\
\text { you're finance or business development or marketing, when you're in the } \\
\text { hotels and you spot people who are really good, notice it, you know get a } \\
\text { note of the name, make sure that we're also all talent spotting our own } \\
\text { people." HR Vice President Euroalliance } \\
\text { "We must therefore nurture excellence in every one of our employees, } \\
\text { especially our local nationals - the people who live in the countries } \\
\text { where we operate hotels." Vice President HR EAME Contractman } \\
\text { International } \\
\text { "At the Vice President and divisional director levels we're always } \\
\text { travelling, listening to what are people are saying and telling them about }\end{array}$ \\
\hline
\end{tabular}




\begin{tabular}{|c|c|c|c|}
\hline & FranchiseKing & $\begin{array}{l}\text { number } 2 \text { manager. Thus we have effectively } \\
\text { stopped developing this 'almost' risk free human } \\
\text { resource - it may cause us problems in the long } \\
\text { term." Vice President HR USmixedeconomy }\end{array}$ & $\begin{array}{l}\text { what's happening across the company. And spotting talent too." Anglo- } \\
\text { American Premium Vice President of HRs }\end{array}$ \\
\hline $\begin{array}{c}\text { (6) where } \\
\text { specific career } \\
\text { interventions } \\
\text { emerge }\end{array}$ & $\begin{array}{l}\text { "Our restructuring of brands and } \\
\text { growth in franchising means we have to } \\
\text { be clear about what managers do to } \\
\text { make the hotels successful. Our company } \\
\text { University is critical for training to our } \\
\text { brands so all our managers know." } \\
\text { Assistant HR director for Euromultigrow } \\
\text { EAME } \\
\text { "Performance of our business is crucial } \\
\text { and that is why so much investment and } \\
\text { development had been made in this area } \\
\text { of competencies and performance } \\
\text { management. There's been a clear } \\
\text { growth in profits since the competencies } \\
\text { were first developed." Vice President for } \\
\text { HR FranchiseKing }\end{array}$ & $\begin{array}{l}\text { "In fact it is incredibly incestuous and people } \\
\text { just seem to appear or materialise. We wouldn't } \\
\text { directly poach someone, well ..., but if someone } \\
\text { made it clear to us they'd be interested then } \\
\text { we'd feel fine about calling them up." Britbuyer } \\
\text { HR EAME director } \\
\text { "When we go outside, well we steal from the } \\
\text { competition and just rely on the grapevine or } \\
\text { maybe on-spec applications. There's some use of } \\
\text { executive search but that's very expensive." } \\
\text { Regional HR director USmixedeconomy }\end{array}$ & $\begin{array}{l}\text { Potential GMs ... } \\
\text { It's very intensive (the assessment centre) with personal counselling, tests } \\
\text { to see where their stresses and strains are, and management skills across } \\
\text { the board, running from } 8 \text { in the morning to } 10 \text { at night. It's really very } \\
\text { intensive and we have people from across the world, with different } \\
\text { languages and cultures, the mix of people is seen to be the best element of } \\
\text { these events. "Anglo-American Premium Vice President of HRs } \\
\text { "For the assessment centre a report is written on them based on what we } \\
\text { feel they demonstrated, in the way they acted during the course. What is } \\
\text { okay and the right way, what's to be demonstrated and what's to be } \\
\text { discussed, where they feel they need development in, and from that we } \\
\text { can more or less determine the time span its going to take so that they'll } \\
\text { be ready to be a GM, and what has to happen in-between so the } \\
\text { individual development is planned." Corporate Director of Human } \\
\text { Resources Globalalliance } \\
\text { "they all go on a leadership development programme and I design and I } \\
\text { teach those with a co-trainer, I like to see that I'm there with them for a } \\
\text { full week and we run an assessment process with the leadership } \\
\text { development programme. So they're booked for tests and exercises based } \\
\text { on the four management skills areas and they have individual feedback } \\
\text { during the brief to let them know how they're doing. This sets them with } \\
\text { an individual plan for the future" HR Vice President Euroalliance }\end{array}$ \\
\hline
\end{tabular}


Table 4. The IHC Strategic Groups, their strategic variables and the HRM outcomes

\begin{tabular}{|c|c|c|c|}
\hline & Strategic groups & Strategic group variables & HRM outcomes \\
\hline \multirow{3}{*}{ 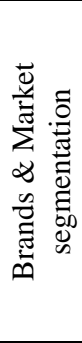 } & Multi-branders & $\begin{array}{l}\text { - Hard brands, serving several different } \\
\text { market levels. }\end{array}$ & $\begin{array}{l}\text { - Allows more localisation of management talent due to standardisation and clear criteria for operating } \\
\text { brands. } \\
\text { - Movement within and between brands facilitated to prevent career bottlenecks. }\end{array}$ \\
\hline & $\begin{array}{l}\text { Mixed Portfolio } \\
\text { Purchasers }\end{array}$ & $\begin{array}{l}\text { - Some soft (international) and some hard } \\
\text { (domestic) brands. }\end{array}$ & $\begin{array}{l}\text { - Difficult to facilitate movement between international brands due to recent purchases, no transfer between } \\
\text { domestic and international brands due to skills mismatch. } \\
\text { - Importance of communication to assimilate new acquisitions }\end{array}$ \\
\hline & Prestige Operators & - $\quad$ Softer brands. & $\begin{array}{l}\text { Emphasis on transfers to develop managerial experience of different countries/markets, and types of } \\
\text { hotels } \\
\text { Encourages and facilitates employees at all levels to gain international experience }\end{array}$ \\
\hline \multirow{3}{*}{ 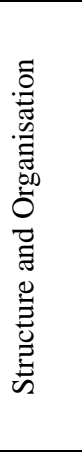 } & Multi-branders & $\begin{array}{l}\text { - Large diverse organisations, structured on } \\
\text { the basis of brands and some geographical } \\
\text { factors. } \\
\text { - } \quad \text { Critical mass of units in some locations }\end{array}$ & $\begin{array}{l}\text { - Companies have developed guides to articulate management positions and skills across brands } \\
\text { - Critical mass allows multi-unit UGMs and more local recruitment and selection activities. }\end{array}$ \\
\hline & $\begin{array}{l}\text { Mixed Portfolio } \\
\text { Purchasers }\end{array}$ & $\begin{array}{l}\text { - Organised on International and domestic } \\
\text { divisions. Slow assimilation of newly } \\
\text { purchased international brands } \\
\text { - } \quad \text { Some critical mass of units. }\end{array}$ & $\begin{array}{l}\text { - Some local recruitment and selection, less development through strong internal labour market and more } \\
\text { acquisition of management talent. } \\
\text { Critical mass allows more localisation of management talent but not co-ordinated effectively throughout the } \\
\text { companies. }\end{array}$ \\
\hline & Prestige Operators & $\begin{array}{l}\text { - Smaller portfolios organised on regional } \\
\text { lines. } \\
\text { - } \quad \text { Limited critical mass of units }\end{array}$ & $\begin{array}{l}\text { - Regional offices co-ordinate transfers and HRM practices but also learn from subsidiaries to pass } \\
\text { experience, knowledge and expertise on across other regions. IT plays an important role here. } \\
\text { Across company recruitment and development schemes rather than localised versions. Provides single } \\
\text { ports of entry at (sub) department management level to locals. }\end{array}$ \\
\hline \multirow{3}{*}{ 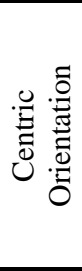 } & Multi-branders & - $\quad$ Primarily ethnocentric & $\begin{array}{l}\text { - Highly standardised services seem to facilitate low reliance on PCNs at subsidiary level though they are } \\
\text { prevalent at executive level }\end{array}$ \\
\hline & $\begin{array}{l}\text { Mixed Portfolio } \\
\text { Purchasers }\end{array}$ & $\begin{array}{l}\text { - } \quad \text { Difficult to discern - bypassing of stages } \\
\text { through acquisitions (McKiernan, 1992) }\end{array}$ & $\begin{array}{l}\text { - PCNs still mainly in place for acquired companies, some locations with HCNs (critical mass) but dominated } \\
\text { by Western nationals. }\end{array}$ \\
\hline & Prestige Operators & - $\quad$ Aspiring geocentric & $\begin{array}{l}\text { - Attempts to harness managerial talent from around the world regardless of nationality through co- } \\
\text { ordinated and integrated HRM activities. } \\
\text { - UGMs still primarily from Western (European and American) backgrounds, executives in particular. }\end{array}$ \\
\hline \multirow{3}{*}{ 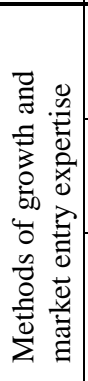 } & Multi-branders & $\begin{array}{l}\text { - Growth through hard brands and the } \\
\text { development of suitable investors (master } \\
\text { franchisees and owners) }\end{array}$ & $\begin{array}{l}\text { - UGMs have specific knowledge and skills in operating highly standardised hotel services and passing } \\
\text { knowledge onto others (franchisees) } \\
\text { - HRM mechanisms define performance and selection criteria for managers and employees. }\end{array}$ \\
\hline & $\begin{array}{l}\text { Mixed Portfolio } \\
\text { Purchasers }\end{array}$ & $\begin{array}{l}\text { - Acquisition used alongside mixed methods } \\
\text { of market entry (mainly management } \\
\text { contracts). }\end{array}$ & $\begin{array}{l}\text { - UGMs are likely to have expertise in exploiting value from purchased properties } \\
\text { - De-layering of organisational hierarchies (disappearance of deputy UGM position) and local recruitment } \\
\text { initiatives were seen to help realise returns on their acquisitions }\end{array}$ \\
\hline & Prestige Operators & $\begin{array}{l}\text { Growth primarily through management } \\
\text { contracting, some marketing } \\
\text { agreements, and equity investment. } \\
\text { Global but local outlook }\end{array}$ & $\begin{array}{l}\text { - Managers demonstrate specific proficiency in managing more luxurious and culturally adapted hotels } \\
\text { and their owners. } \\
\text { - More extensive and integrated HRM interventions, which support extensive transfers and development } \\
\text { opportunities, throughout human resources, not just managers }\end{array}$ \\
\hline
\end{tabular}


